\title{
BATIK GAYA MODERN DI SURAKARTA DALAM PERSPEKTIF QUANTUM
}

\section{Surakarta 's Modern style Batik in Quantum Perpective}

\author{
Sujadi R. Hidayat', Rustopo ${ }^{2}$, dan Dharsono ${ }^{2}$ \\ ${ }^{1}$ Program Studi Kriya Seni Fakultas Seni Rupa dan Desain Universitas Sebelas Maret, \\ ${ }^{2}$ Program Pascasarjana Institut Seni Indonesia Surakarta
}

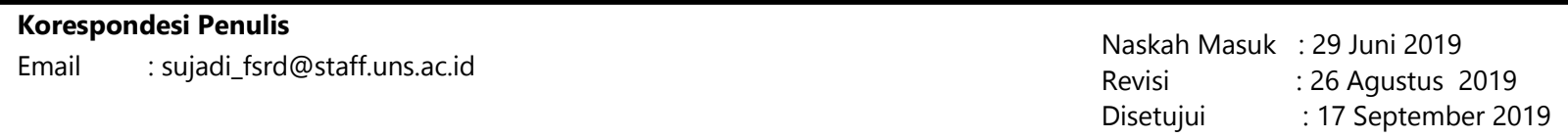

Kata kunci: batik, gaya, modern, Surakarta, quantum

Keywords: batik, style, modern, Surakarta, Quantum

\begin{abstract}
ABSTRAK
Peningkatan apresiasi terhadap batik gaya modern di Surakarta pada awal abad XXI merupakan fenomena penting untuk dipelajari sebagai referensi untuk terus menjaga kelangsungan batik. Apresiasi terhadap batik gaya modern dipengaruhi oleh wujud seni dan esensi dari karya yang dikreasi oleh penciptanya. Kajian ini bertujuan untuk memahami dan menjelaskan wujud dan esensi batik gaya modern di Surakarta pada awal abad XXI. Metode yang digunakan dalam kajian permasalahan melalui penelitian deskriptif kualitatif studi kasus pada karya Pandono. Metode pengumpulan data yang dignakan adalah wawancara, observasi, analisis dokumen, dan studi pustaka. Setelah dilakukan analisis terhadap data yang terkumpul, diketahui bahwa wujud batik gaya modern yang dikembangkan di Surakarta pada awal abad XXI tidak mengacu pada pakem visual batik gaya klasik ataupun batik tradisi lainnya, namun seringkali masih mengambil bentuk-bentuk khas dari batik klasik untuk diolah dengan prinsip desain yang berbeda sebagai penanda bahwa batik gaya modern tersebut masih terdapat benang merah dengan batik klasik. Esensi batik gaya modern lebih bersifat profan sebagai ekspresi keindahan dan bentuk kecintaannya terhadap tradisi melalui inovasi tradisi bukan pembekuan tradisi.
\end{abstract}

\section{ABSTRACT}

Increased appreciation of modern style batik in Surakarta at the beginning of the XXI century is an important phenomenon to be studied as a reference to keep maintaining the sustainability of batik. Appreciation towards modern style batik is influenced by the form of art and the essence of the work created by its creator. This study aims to understand and explain the form and essence of modern style batik in Surakarta at the beginning of the XXI century. The method used in this study is through qualitative descriptive case study in Pandono's work. Data collection methods used were interviews, observation, document analysis, and literature study. After analyzing the collected data, it is known that the form of modern style batik developed in Surakarta at the beginning of the XXI century does not refer to the classical visual style of batik or other traditional batik, but often still takes the typical forms of classic batik to be processed by different designs principle as a marker that modern style batik still has some "red thread" with classic batik. The essence of modern-style batik is more profane as an expression of beauty and a form of love for tradition through innovation rather than tradition freezing. 


\section{PENDAHULUAN}

Eksistensi batik Surakarta sudah ada selama berabad-abad dan tetap bertahan sampai hari ini, meskipun sampai sekarang belum ada hasil riset menjelaskan tentang awal munculnya batik di Surakarta. Dharsono (2007) dalam bukunya berjudul Budaya Nusantara menjelaskan tentang dinamika batik utamanya batik Surakarta. Pada abad XVI, batik merupakan komoditas perdagangan mewah di mana hanya orangorang yang berada saja yang bisa memilikinya. Oleh karena batik merupakan barang yang istimewa di mata masyarakat, pada abad XVIII, Istana (kraton Surakarta) mengembangkan batik. Kraton mulai mengumpulkan para ahli batik untuk memproduksi batik di dalam Istana. Istana mulai menciptakan motif-motif batik baru yang sekarang dikenal dengan motif batik kraton atau batik klasik. Selain menciptakan motif batik klasik, Raja juga mengatur tentang penggunaan motif batik. Pada abad XX produksi batik Istana mengalami penurunan sehingga memberi peluang untuk berkembangnya batik di luar Istana. Daerah perbatikan yang berkembang pada saat itu antara lain di Laweyan Kota Surakarta. Sentra batik yang berkembang saat itu antara lain: Laweyan, Kedungggudel (Sukoharjo), Bekonang (Sukoharjo), Kliwonan (Sragen), Plupuh (Sragen), Serenan (Klaten), Tirtomoyo (Wonogiri), dan Matesih (Karanganyar). Daerah perbatikan tersebut merupakan pusat-pusat produksi batik yang menyangga eksistensi batik di Surakarta sampai saat ini (Kalinggo Honggodipuro, 2002), (Doellah, 2002), (Dharsono, 2007).

Kehidupan batik di Surakarta berlangsung begitu dinamis mengikuti perkembangan zaman dan lingkungan.
Karena kehidupannya yang begitu dinamis, maka di Surakarta muncul beragam gaya batik. Gaya batik yang pernah muncul di Surakarta antara lain: batik klasik gagrag Surakarta (batik gaya Kasunanan dan batik gaya Mangkuneran), batik Wonogiren, batik Petanen, batik Sudagaran, batik Indonesia, batik Tiga Negeri, dan juga muncul batik gaya modern.

Batik modern adalah semua macam jenis batik yang motif dan gayanya tidak seperti batik tradisional. Batik modern adalah batik yang menyimpang dari ikatan batik tradisional (Susanto, 1980). Batik modern mencerminkan bentuk motif, fungsi, dan teknik produksinya yang merupakan aspirasi dari budaya modern (Suyanto, 2002). Tulisan lain mengartikan batik modern sebagai batik dengan motif yang tidak terikat aturan tradisi atau pakem, namun tetap berkait erat dengan unsur titik, garis, warna, bidang, pola, dan motif (Saputro, 2009).

Gaya seni merupakan sebuah pengelompokan atau klasifikasi karya-karya seni (melalui waktu, daerah, wujud, teknik, tema, dan lain-lain) yang membuat kemungkinan studi dan analisis lebih jauh. Gaya merupakan penyatuan unsur yang dapat dilihat secara langsung seperti: warna, bidang, garis, tekstur, atau dapat juga dideteksi dalam sebuah hubungan kualitatif antar unsur tersebut. Gaya dibedakan tidak hanya berdasar pada apa yang dilihat pada sebuah karya tetapi seluruh kualitas yang tampil oleh suatu karya. Gaya yang ditampilkan dalam karya dapat membimbing kita mencari makna dibalik tema dan mengetahui tujuan penciptaan karya. Suatu pengetahuan tentang gaya banyak menyatakan tentang cara berpikir 
seniman, tentang lingkungannya, dan tentang masyarakat dan kebudayaan dari mana karya berakar (Feldman, 1967). Gaya, corak, atau langgam dapat disejajarkan dengan istilah Inggris 'style', adalah modus berekspresi dalam mengutarakan sesuatu bentuk. Hal ini berarti gaya, corak, atau langgam ini berurusan dengan bentuk luar suatu karya seni. Gaya timbul karena kebutuhan, suatu konsep yang dengan sadar ingin dicapai lewat karya-karyanya (Soedarso, 2006).

Berdasar pada berbagai rujukan di atas, maka dapat dijelaskan bahwa batik gaya modern adalah karya batik dengan unsur visual, struktur visual, ataupun pola berbeda dari batik klasik atau batik tradisi. Mengingat tulisan ini membahas tentang batik gaya modern di Surakarta, maka karya yang dibahas adalah batik gaya modern yang dihasilkan di Surakarta. Selain itu, pakem tradisi yang digunakan sebagai dasar pijakan untuk menyebut batik gaya modern adalah batik gagrak Surakarta dan gayagaya pengembangannya.

Eksistensi batik gaya modern di Surakarta pada awal abad XXI (mulai tahun 2008) mengalami perubahan yang cukup signifikan. Batik gaya modern, yang awal kemunculannya kurang mendapat apresiasi bahkan ditolak oleh sebagian orang, kini banyak dicari dan diapresiasi sebagai karya batik yang inovatif. Salah satu apresiasi yang cukup tinggi adalah pada Oktober 2018 batik gaya modern dari Surakarta tampil dalam perhelatan internasional yang bertajuk Jogja International Batik Bienale 2018. Apresiasi masyarakat, dalam bentuk konsumsi atau pemakaian produk batik gaya modern pada beberapa puluh tahun terakhir cukup baik dan bahkan cenderung meningkat. Saat ini penjualan batik gaya modern cukup baik, bahkan produsen terkadang kewalahan dalam memenuhi pesanan konsumen.

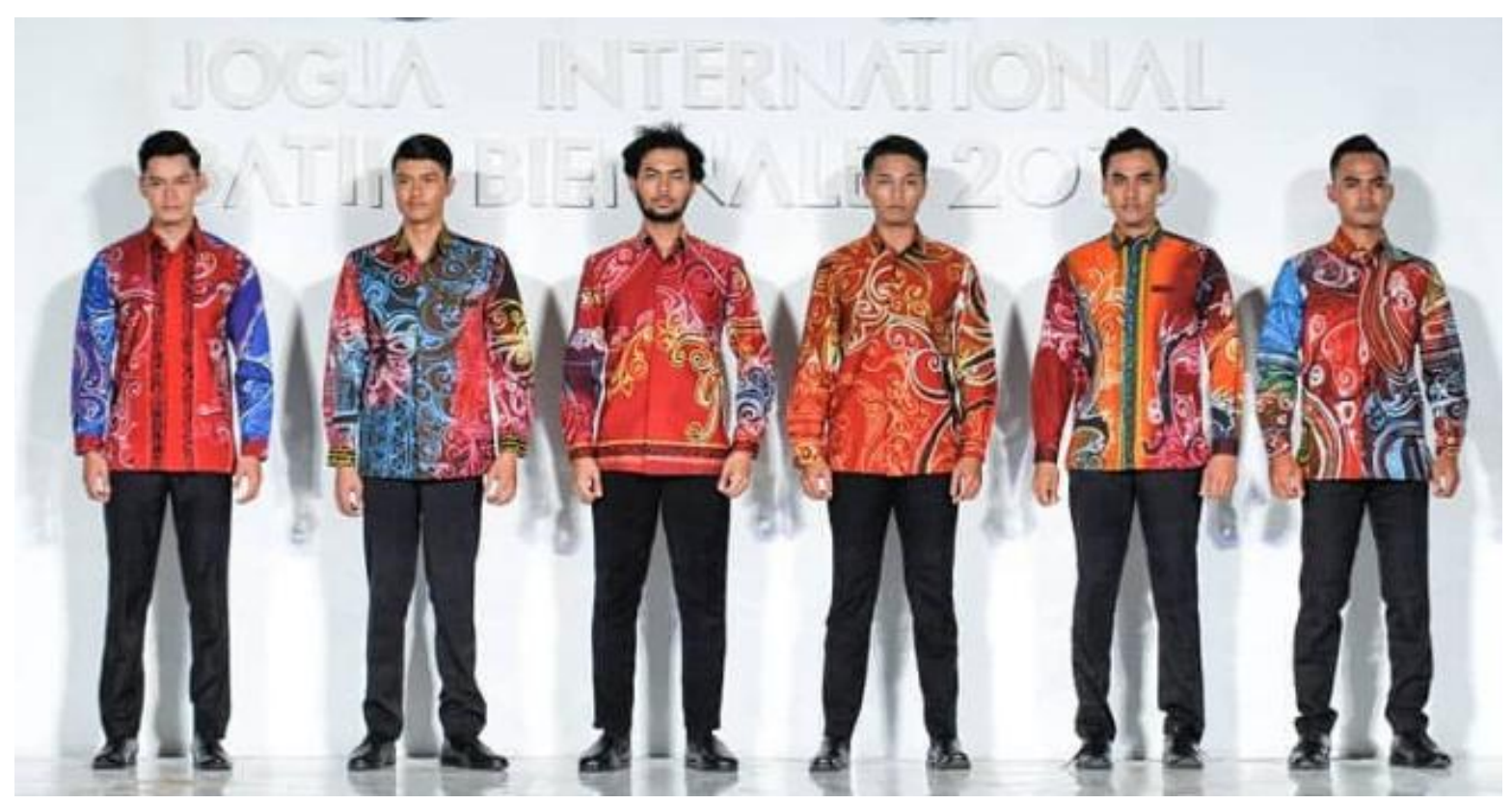

Gambar 1. Batik Kontemporer karya Pandono tampil dalam perhelatan Jogja International Batik Bienale (JIBB) pada Oktober 2018 di Yogyakarta 
Peningkatan apresiasi masyarakat terhadap batik gaya modern merupakan fenomena yang menarik dan penting untuk dikaji. Kehidupan kesenian didukung oleh tiga komponen utama yang saling berinteraksi secara kreatif dan dinamis, yaitu seniman, karya seni, dan penghayat (Dharsono, 2017). Interaksi secara kreatif dan dinamis terjadi dalam aktivitas kreasi dan apresiasi. Apresiasi seseorang terhadap karya seni dipengaruhi oleh wujud seni dan esensi dari seni yang dikreasi oleh penciptanya. Pengetahuan tentang wujud dan esensi batik gaya modern di Surakarta pada awal abad XXI dapat digunakan untuk memahami terjadinya apresiasi. Memahami wujud dan esensi berarti akan memahami kehidupan kesenian itu sendiri, dan selanjutnya bisa digunakan untuk menjaga kelangsungannya. Pembahasan wujud dan esensi dari batik gaya modern dilakukan dengan pendekatan teori quantum dalam seni.

Teori quantum adalah teori yang menyatakan bahwa pada level sub-atomik, semua materi dan energi, apapun itu, pada saat yang sama memiliki properti sebagai partikel sekaligus gelombang. Segala sesuatu adalah dualitas, terdiri dari partikel atau gelombang, yang dinamakan dualitas quantum. Karya seni ataupun fenomena seni apa saja akan dilihat sebagai dualitas, sebagai partikel (aspek material) dan gelombang (aspek immaterial). Secara bolak balik, seni dikaji dari aspek fisiknya maupun makna yang terkait padanya. Seni dapat dilihat sebagai objek dan sekaligus sebagai subjek (Marianto, 2017).

Permasalahan yang dibahas dalam kajian ini adalah tentang wujud dan esensi batik gaya modern di Surakarta dengan studi kasus karya batik Pandono dari Laweyan Surakarta. Tujuan pembahasan tentang wujud adalah menjelasakan tentang bentuk dan struktur karya batik gaya modern karya Pandono dari Laweyan Surakarta. Tujuan kedua dari kajian ini adalah menjelaskan tentang esensi karya batik gaya modern, yang mana akan dibahas tentang ekspresi dari karya tersebut.

\section{METODOLOGI PENELITIAN}

Pembahasan permasalahan dilakukan melalui penelitian dengan metode deskriptif kualitatif yang dilakukan di Surakarta pada akhir tahun 2018 sampai awal 2019 dalam bentuk studi kasus pada karya Pandono. Sumber data primer yang digunakan adalah tiga orang pembuat batik gaya modern di Surakarta. Tiga orang tersebut sama-sama tinggal di Surakarta namun memiliki latar belakang kehidupan yang berbeda-beda. Pertama, Pandono adalah salah satu generasi muda dalam dunia perbatikan yang fokus mengembangkan batik gaya modern. Kedua, Saud Effendi adalah anak seorang juragan batik yang sejak awal ikut berperan dalam pengembangan batik gaya modern di Surakarta. Ketiga, Sri Uningsih adalah perancang dan pengusaha batik gaya modern di Surakarta yang terlahir bukan dari keluarga pembatik. Teknik pengumpulan data dengan wawancara, observasi, analisis dokumen, dan studi pustaka. Validitas data menggunakan teknik trianggulasi sumber data. Data dari suatu sumber dikonfirmasi dengan sumber data yang lain baik yang sejenis maupun beda jenis datanya (Sutopo, 2002). Analisis data menggunakan teknik analisis interaktif, yang bergerak pada reduksi data, sajian data, dan penarikan simpulan, yang dilakukan sejak proses 
pengumpulan data berlangsung (Miles \& Huberman, 1994). Pembahasan mengenai wujud menggunakan konsep unsur dan struktur visual yang dikemukakan oleh Lois dan Ratus. Pembahasan tentang esensi batik gaya modern dilihat dari perspektif teori estetika Monroe C. Beardsley dan teori fungsi personal seni yang dikemukakan oleh Edmund Burke Feldman.

\section{HASIL DAN PEMBAHASAN}

Batik karya Pandono yang digunakan sebagai purposive sampling dalam pembahasan batik gaya modern di Surakarta adalah sebagai berikut pada Gambar 2.

\section{Wujud Batik Gaya Modern di Surakarta}

Wujud seni dalam perspektif quantum merupakan partikel atau aspek material dari sebuah karya. Pembahasan tentang wujud berarti membahas tentang objek atau segala sesuatu yang bisa dilihat dan dirasa pada karya batik gaya modern. Membahas wujud karya seni berarti membahas tentang estetika karya tersebut.
Memahami estetika sebenarnya menelaah firma seni yang kemudian disebut struktur desain atau struktur rupa; yang terdiri dari unsur desain, prinsip desain, dan asas desain. Unsur visual dalam sebuah karya seni rupa terdiri dari garis, shape (bangun), tekstur, warna, ruang dan waktu (Dharsono, 2007). Prinsip desain yang digunakan sebagai dasar dalam pengorganisasian unsur visual dalam karya seni meliputi: rhythm, unity, balance, emphasis, proportion, clarity, dan simplicity. Adapun clarity dan simplicity lebih diterapkan untuk bidang desain atau seni terapan (Sanyoto, 2009).

Unsur garis pada visual batik gaya modern karya Pandono menampilkan dua jenis garis yang memiliki karakter yang berbeda, namun bisa hadir dengan harmonis. Jenis garis pertama, merupakan garis yang dihasilkan dari goresan canting tulis yang menghasilkan visual non geometri dengan karakter lembut, luwes dan lemah gemulai. Jenis garis kedua, merupakan garis yang dihasilkan dari penyiraman cairan malam (lilin batik) panas pada permukaan .

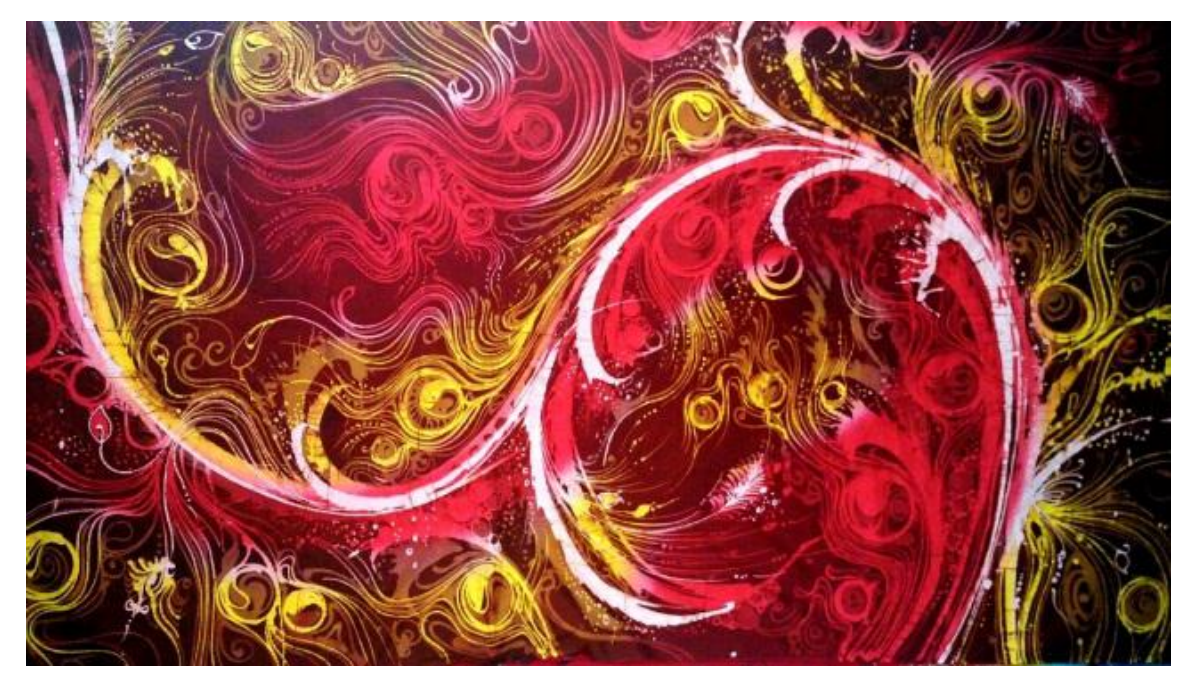

Gambar 2. Batik Gaya Modern Karya Pandono

(sumber: Dokumentasi digital milik Pandono, tahun 2016) 
kain dengan cepat dan terarah. Garis yang dihasilkan dengan dimensi yang cukup tebal dengan bentuk lengkung. Goresan garis dengan teknik siraman yang cepat dan terarah menghasilkan bentuk garis lengkung dengan efek cipratan-cipratan cairan kental pada satu sisi. Garis tersebut memiliki kesan yang kuat, cepat, namun dinamis. Dua garis yang berkarakter beda tersebut dapat tampil bersamaan dengan harmonis karena terdapat kesamaan dari keduanya, yaitu sama-sama garis non geometri yang memiliki sifat dinamis

A

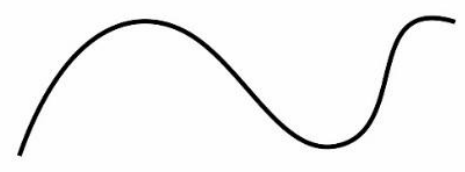

B

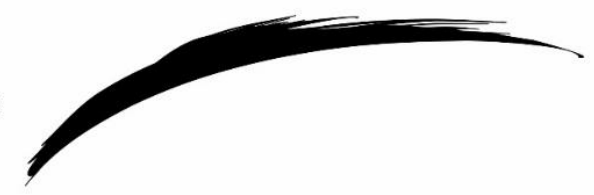

Gambar 3. (A) Jenis garis non geometri dengan karakter halus dan lemah lembut, (B) Jenis garis non geometri dengan karakter tegas dan cepat

Batik gaya modern karya Pandono tidak begitu menampilkan unsur bangun (shape) secara eksplisit. Jika kita lihat secara detail, unsur bangun yang ada pada karya tersebut hanya berupa bulatan-bulatan yang menggambarkan daun secara deformatif dengan stilisasi bentuk. Bangun yang berbentuk bulatan-bulatan tersebut tidak begitu tampak karena hanya berupa kontur (garis tepi), sedangkan bagian tengah berwarna transparan atau sesuai warna di belakangnya. Namun jika kita lihat secara keseluruhan, garis-garis yang tersusun di sana membentuk sebuah shape yang menggambarkan tanaman yang merambat (lung-lungan). Lung-lungan tersebut tervisualkan dengan luwes dan indah lengkap dengan bunga, daun, maupun sulur-suluran. Kesan tekstur (tekstur semu) seperti guratan yang dihasilkan dari garisgaris sejajar yang meliuk-liuk hasil goresan canting yang begitu luwes menjadikan /unglungan tampil semakin indah.

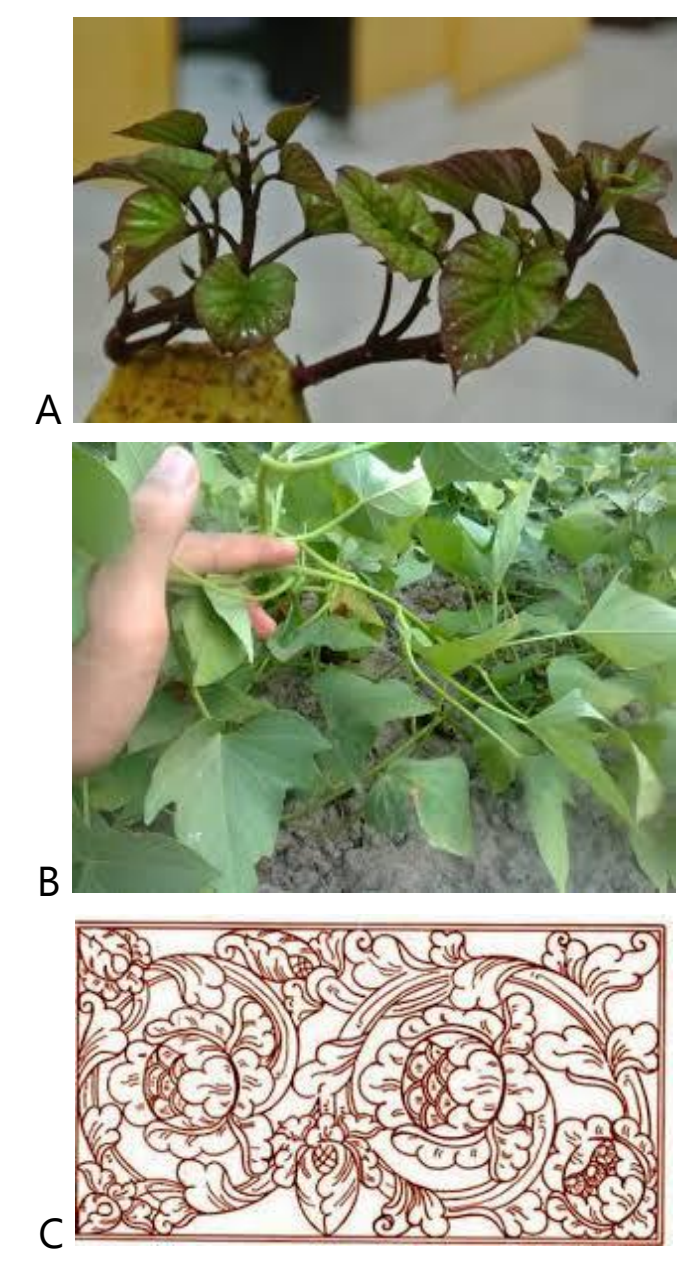

Gambar 4. (A) Tanaman lung yang baru tumbuh,

(B) Tanaman lung yang sudah menjalar, (C) Visualisasi tanaman lung dalam ornamen tradisi

Komposisi warna yang digunakan Pandono dalam karyanya tersebut adalah kontras split komplemen. Komposisi tersebut menggunakan warna yang berseberangan pada lingkaran warna, tetapi menyimpang ke kiri atau ke kanan. Warna split komplemen macamnya cukup banyak. 
Misalkan warna split komplemen dari kuning, bisa merah, merah ungu, biru ungu, atau biru (Sanyoto, 2009).

Batik merupakan karya seni rupa dalam kelompok dua dimensi (dwimatra) yang secara umum hanya menampilkan ruang dalam bentuk bidang dengan dimensi panjang dan lebar. Batik kontemporer karya Pandono mampu memunculkan ruang tiga dimensi dalam bentuk trimatra semu atau ruang semu. Ruang semu artinya indera penglihatan menangkap bentuk dan ruang sebagai gambaran sesungguhnya yang tampak pada taferil dua matra (Dharsono, 2007b), (Sanyoto, 2009). Ruang semu atau kesan meruang yang tampak pada karya Pandono dihasilkan dari penggunaan warna gradasi dari kuning ke coklat gelap dan merah ke coklat gelap. Bagian warna coklat gelap seakan berada jauh di belakang dan warna-warna terang seperti putih dan kuning seakan berada pada bagian paling depan.

Elemen-elemen visual pada karya batik, berupa garis, bentuk, warna, maupun teksur dapat menjadi karya yang artistik karena ada pengorganisasi atau penataan. Penataan atau pengorgaisasian elemen visual agar menjadi objek yang artistik menggunakan prinsip desain yang meliputi: rhythm, unity, balance, emphasis, dan proportion. Sebenarnya prinsip desain masih ada lagi yang lain selain dari kelima prinsip tersebut, namun dalam hal ini hanya akan dibahas lima prinsip yang paling utama dalam penyusunan karya seni.

Rhythm atau ritme atau irama atau keselarasan adalah gerak perulangan atau gerak mengalir/aliran yang ajeg, runtut, teratur, terus-menerus. Keajegan dalam irama artinya bisa pengulangan dengan kesamaan, pengulangan dengan perubahan dekat, pengulangan dengan kekontrasan. Ajeg merupakan istilah Jawa yang artinya terus menerus dengan jarak, waktu, gerak, yang sama. Dengan demikian, terdapat dua hal pokok dalam membahas irama, yaitu pengulangan dan aliran (Sanyoto, 2009).

Irama yang diterapkan oleh Pandono dalam karya batik kontemporer berbeda dari irama dalam batik klasik pada umumnya. Pada batik klasik cenderung menerapkan irama dengan susunan repetisi, yang memunculkan garis semu yang berulang cenderung sejajar. Motif batik klasik dengan irama susunan repetisi seperti kawung, truntum, sidomukti, dan kelompok pola parang dan lereng. Pada pola non geometri, seperti semen dan lung-lungan, meskipun secara sepintas garis semu tidak muncul, namun ketika dilihat secara keseluruhan dalam satu jarik maka akan tampak juga irama susunan repetisi. Pada karya Pandono menerapkan dua irama, yaitu irama susunan transisi dan susunan oposisi. Susunan transisi merupakan susunan dengan gerak semu berulang dengan perubahan-perubahan dekat, yaitu bentuk garis-garis lengkung yang dihasilkan dari siraman cairan malam panas yang cepat dan terarah. Garis-garis lengkung berwarna putih, merah, dan kuning disusun membentuk lengkungan yang menyerupai tanaman menjalar yang sedang tumbuh (/ung-/ungan). Susunan garis-garis lengkung dengan dimensi yang cukup tebal dan warna yang kuat, menjadi irama utama dalam karya Pandono. Ruang-ruang diantara garis garis lengkung sebagai objek utama diberi pengisi dengan garis-garis lembut yang dihasilkan dengan goresan canting. Irama yang diterapkan pada garis- 
garis lembut tersebut adalah susunan oposisi, karena garis semu yang ada saling berpotongan dan bertentangan sehingga menghasilkan komposisi yang keras, kuat, tajam, dan dinamis. Garis yang berkarakter kuat, cepat, keras disusun dengan irama transisi yang lembut, sedangkan garis yang lembut dan lemah gemulai disusun dengan irama oposisi yang kuat dan keras. Perpaduan dua irama tersebut menjadikan karya yang artistik dan unik.

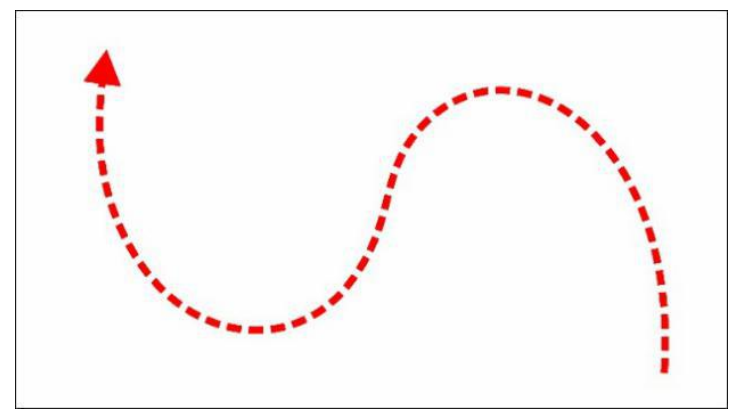

Gambar 5. Garis semu yang dimunculkan dari irama susunan transisi pada karya Pandono

Unity bisa juga disebut dengan keutuhan atau kesatuan, yaitu kemanunggalan menjadi satu utuh. Karya seni harus tampak menyatu atau menjadi satu keutuhan, seluruh elemen yang disusun saling mendukung, tidak ada bagian yang mengganggu, atau keluar atau terpisah dari susunan. Prinsip dasar unity adalah adanya saling hubungan antar elemen yang disusun.Hubungan dalam elemen seni rupa terjalin karena adanya kesamaan, kemiripan, keselarasan, keterikatan, atau kedekatan (Sanyoto, 2009).

Keutuhan karya batik kontemporer Pandono terjalin dengan sangat baik. Terdapat dua strategi yang diterapkan dalam mewujudkan unity dalam karya, yaitu dengan menggunakan pendekatan kemiripan (similarity) unsur visual dan pendekatan pengaitan unsur visual. Unsur visual berupa garis-garis lengkung yang lembut dan lemah gemulai dan bulatanbulatan dengan berbagai warna cukup mendominasi tampilan. Kemiripan bentuk elemen-elemen visual yang digunakan menjadikan kesatuan dengan mudah akan terjalin. Selain itu, kesatuan semakin kuat dengan adanya garis-garis lengkung tegas dan kuat dengan warna terang yang dihasilkan dengan siraman cairan malam panas. Garis tersebut seakan menjadi pengikat dari keseluruhan unsur visual dalam karya tersebut.

Emphasis adalah pemberian tekanan pada bagian tertentu sebagai pusat perhatian. Istilah lain dari emphasis antara lain aksentuasi, dominasi, centre of interest, eye catcher, focal point, eye pathway. Emphasis berfungsi untuk menarik perhatian, menghilangkan kebosanan, memecahkan rutinitas, atau sebagai kejutan. Emphasis dapat dilakukan dengan beberapa cara seperti: pemberian tekanan melalui perulangan, pemberian tekanan melalui ukuran, pemberian tekanan melalui kontras bentuk, warna, atau tekstur, ataupun pemberian tekanan melalui susunan yang mengarahkan pandangan pada satu pusat ((Dharsono, 2007), (Sanyoto, 2009).

Aksentuasi pada batik karya Pandono yang diberikan untuk memberi kejutan dan menarik perhatian adalah dengan menerapkan dominasi kontras bentuk, ukuran, dan warna. Unsur visual yang mendominasi dalam tata susun tersebut adalah garis-garis lengkung yang dihasilkan dari penyiraman cairan malam panas yang cepat dan terarah. Dimensi garis yang cukup besar dengan efek cipratan dan berwarna terang mendominasi unsur visual lain yang berupa garis-garis lembut, lemah gemulai 
dengan warna yang cenderung lebih gelap. Efek cipratan menjadi emphasis yang mengejutkan dan menarik perhatian dalam karya batik.

Balance merupakan salah satu hukum yang harus diterapkan dalam penyusunan elemen visual, yang mana keadaan atau kesamaan antara kekuatan yang saling berhadapan dan minimbulkan adanya kesan seimbang secara visual ataupun secara intensitas kekaryaan. Keseimbangan dalam dunia seni lebih bersifat pada perasaan, bukan bobot secara fisik (berat benda). Terdapat dua macam keseimbangan yang bisa diterapkan dalam menata elemen visual pada karya, yaitu formal balance dan informal balance (Dharsono, 2007). Dalam formal balance terdapat dua jenis, yaitu keseimbangan simetris dan keseimbangan memancar. Informal balance juga terdapat dua jenis, yaitu keseimbangan sederajat dan keseimbangan tersembunyi (Sanyoto, 2009).

tata susun elemen visual pada karya batik kontemporer Pandono menerapkan sistem keseimbangan informal balance. Elemen visual bagian kiri dan bagian kanan secara umum sama baik dari aspek bentuk maupun warna, namun secara detail bagian kiri dengan kanan bukan merupakan pencerminan. Keseimbangan yang diperoleh dengan sistem informal balance akan tampak lebih dinamis dibanding dengan formal balance.

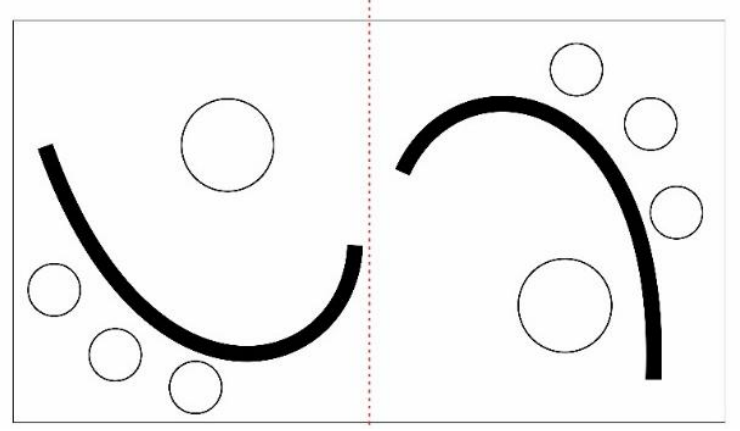

Gambar 6. Skema tata susun dengan informal balance yang diterapkan dalam karya Pandono

Proportion merupakan hubungan komparatif, atau rasio, dari satu hal dengan yang lain dalam karya tersebut (FichnerRathus, 2011). Memahami proporsi yang diproporsionalkan atau ukuran perbandingan yang ideal sebagai alat untuk menciptakan karya seni yang artistik, menarik, atau serasi. Proporsi dilakukan dengan beberapa tujuan: 1) menciptakan keserasian/proporsional; 2) sebagai pemecah masalah; 3) sebagai penyangatan (Sanyoto, 2009).

Batik kontemporer karya Pandono, pada dasarnya, memvisualkan tanaman merambat (/ung-lungan) yang sedang tumbuh subur. Lung-lungan tersebut tumbuh dari ruang kanan bagian bawah merambat ke atas kemudian menjalar melengkung ke arah kiri bawah dan terakhir ujungnya menjalar ke kiri bagian atas. Lunglungan tersebut tumbuh dengan membentuk dua ukel (patran), yang satu berada pada ruang bagian kanan dan yang lain di ruang bagian kiri. Pada batang lunglungan tersebut tumbuh daun-daun, bunga, dan sulur-suluran yang jumlahnya sangat banyak. Sulur-suluran divisualkan dengan garis-garis lembut, sejajar, meliuk-liuk dengan lemah gemulai. Sulur-suluran, daun, dan bunga mengisi ruang-ruang kosong yang ditimbulkan dari lengkungan lunglungan. Proporsi yang menampilkan perbandingan lung-lungan dengan dua uke/ (patran) berukuran besar dipadu dengan daun, bunga, dan sulur-suluran berukuran kecil dengan jumlah banyak menjadikan komposisi yang serasi atau proporsional. Proporsi penyangatan dilakukan untuk mempertegas objek utama selain dengan 
ukuran juga dengan karakter visual yang berbeda dari objek pendukung.

\section{Esensi Batik Gaya Modern di Surakarta}

Monroe Beardsley (1981) menjelaskan bahwa sebuah karya seni atau benda estetis lainnya dikatakan baik atau indah karena ada unity, complexity, dan intensity. Kesatuan (unity) berarti bahwa karya seni tersusun secara baik atau sempurna bentuknya (Beardsley, 1981). Kerumitan (complexity) adalah karya seni tersebut tidak sederhana sekali, melainkan kaya akan isi maupun unsur yang saling berlawanan ataupun mengandung perbedaanperbedaan yang halus. Kesungguhan (intensity) menunjukan adanya suatu kualitas tertentu dalam karya seni, bukan sesuatu yang kosong. Kualitas tidak mempersoalkan tentang apa yang dikandungnya, melainkan tentang bagaimana kesungguhannya dalam menggarap apa yang akan disampaikan (Dharsono, 2007). Esensi sebuah karya seni sangat erat hubungannya dengan fungsi personal dari karya tersebut. Fungsi personal dalam seni terkait dengan karya seni yang difungsikan sebagai media ekspresi pribadi dari sang seniman. Ekspresi pribadi dapat berupa emosi pribadi, tentang persahabatan, dan pandangan-pandangan pribadi seniman terhadap suatu fenomena. Selain itu, ekspresi pribadi juga dapat berupa ekspresi mendasar pada manusia seperti tentang cinta, kematian, sakit, perayaan, dan lain sebagainya (Feldman, 1967).

Intensity atau kesungguhan dalam menggarap apa yang akan disampaikan batik kontemporer dapat terlihat dari proses produksi dan karya yang dihasilkan. Pada dasarnya batik kontemporer masih menerapkan teknik batik dalam proses produksinya, namun secara detail berbeda dari batik klasik. Berdasar standar yang ditetapkan pemerintah Indonesia dengan nomor SNI 0239:2014, yang termasuk katagori batik adalah kerajinan tangan sebagai hasil pewarnaan secara perintangan menggunakan malam (lilin batik) panas sebagai perintang warna dengan alat utama pelekat lilin batik berupa canting tulis dan atau canting cap untuk membentuk motif tertentu yang memiliki makna. Batik kontemporer masih tetap diproduksi oleh tangan manual dengan alat canting tulis ataupun canting cap dan menggunakan malam yang dipanaskan sebagai material perintang warna. Karena batik gaya modern lahir pada saat semangat zaman revolusi industri yang mengejar efisiensi, maka proses batik juga diinovasi agar bisa lebih cepat dibanding batik tradisi. Tahapan proses batik tradisi yang dihilangkan dalam batik gaya modern antara lain proses ngemplong, proses ngerok, dan penggunaan pewarna alam. Untuk mendapatkan jumlah warna yang banyak pada karya, tidak dilakukan dengan tutup celup, melainkan divariasi dengan teknik pewarnaan colet. Zat warna yang digunakan dalam batik kontemporer adalah zat warna sintetis (kimiawi) dengan fiksasi warna jauh lebih cepat dibanding zat warna alam.

Batik merupakan teknik visualisasi gagasan yang cukup rumit prosesnya, membutuhkan waktu yang relatif panjang, namun menghasilkan visual yang unik. Kesungguhan untuk menghasilkan visual yang unik dengan teknik yang rumit merupakan intensity yang ada dalam batik kontemporer. Batik kontemporer harus bisa 
memunculkan bentuk batik yang berbeda dari batik tradisi dan tidak bisa diproduksi dengan teknik printing. Bentuk yang berbeda sebagai upaya gebrakan kebaruan atas kebosanan terhadap batik tradisi. Menciptakan visual yang unik sehingga sulit bahkan tidak mampu diproduksi dengan teknik printing sebagai bentuk perlawanan atas mekanisasi batik. Berdasar pada penjelasan tersebut, abstraksi hasil wawancara dengan Saud Effendi, Pandono, dan Sri Uningsih, dapat diketahui bahwa intensity batik kontemporer menciptakan visual unik melalui teknik batik untuk memperjuangkan kelestarian batik.

Kerumitan teknik dan proses produksi yang diterapkan dalam batik gaya modern juga membawa kompleksitas pada karya yang dihasilkan. Complexity pada karya batik Pandono dapat dilihat dengan jelas dengan adanya perpaduan dua unsur garis yang berbeda karakter namun bisa saling menguatkan. Selain perpaduan dua karakter garis, juga menerapkan pewarnaan gradasi yang mengikuti irama garis sehingga karya begitu kompleks namun harmonis.

Pandono menjelaskan, bahwa karya batik yang diciptakannya tidak memilki makna filosofis seperti pada karya-karya batik klasik atau tradisi. Batik gaya modern hanya mengejar keindahan secara visual, yang meliputi olah bentuk, komposisi bentuk maupun warna. Lung-lungan sebagai sumber ide bentuk dalam penciptaan karya dengan tujuan untuk memperkuat atau menegaskan bahwa batik gaya modern merupakan kelanjutan atau pengembangan dari batik klasik. Menurut Pandono, bentuk-bentuk yang menjadi ciri khas batik tradisi Surakarta antara lain: lunglungan, kawung, dan parang, sehingga batik gaya modern karya dia seringkali mengolah bentuk khas tersebut. Bentuk-bentuk khas tersebut diolah dengan kreatif dan mengabaikan pakem (struktur batik klasik) namun tetap bisa menampilkan kekhasan visual batik.

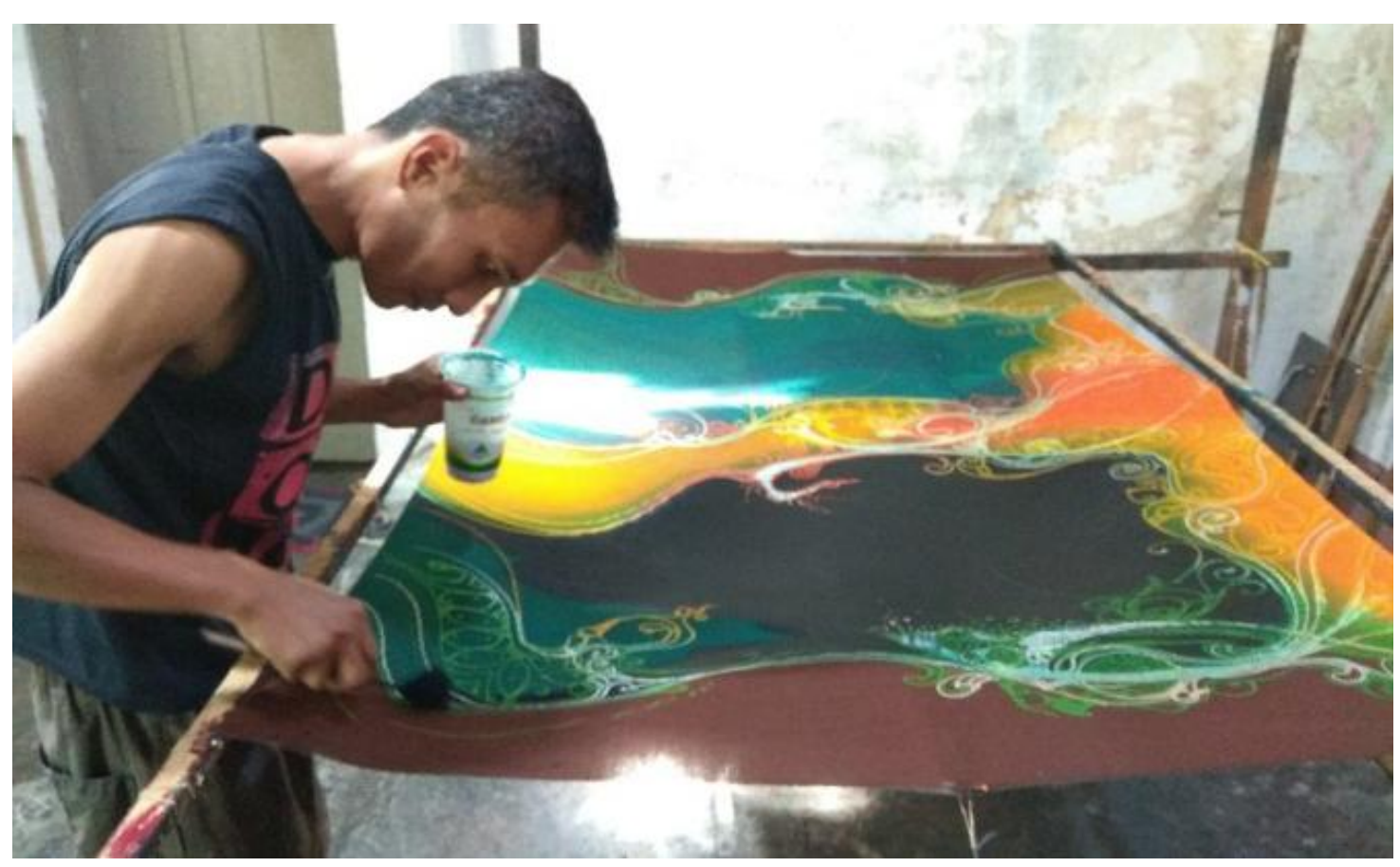

Gambar 7. Proses produksi batik kontemporer di workshop milik Pandono 
mengekspresikan bahwa batik karyanya adalah batik laki-laki. Yang dimaksud dengan batik laki-laki adalah bahwa dunia batik Pandono adalah dijiwai oleh sifat lakilaki, tidak seperti batik tradisi yang lebih dekat pada dunia atau jiwa perempuan. Meskipun Pandono juga menciptakan batik gaya modern untuk perempuan, namun karakter laki-laki tetap muncul pada karya tersebut. Jiwa laki-laki dalam karyanya sudah mulai digarap sejak proses pembuatan. Teknik mbathik (menorehkan malam pada permukaan kain) dengan gerakan-gerakan laki-laki, yaitu cepat dan tegas. Teknik tersebut berbeda dari teknik mbathik pada batik klasik yang serba pelan,

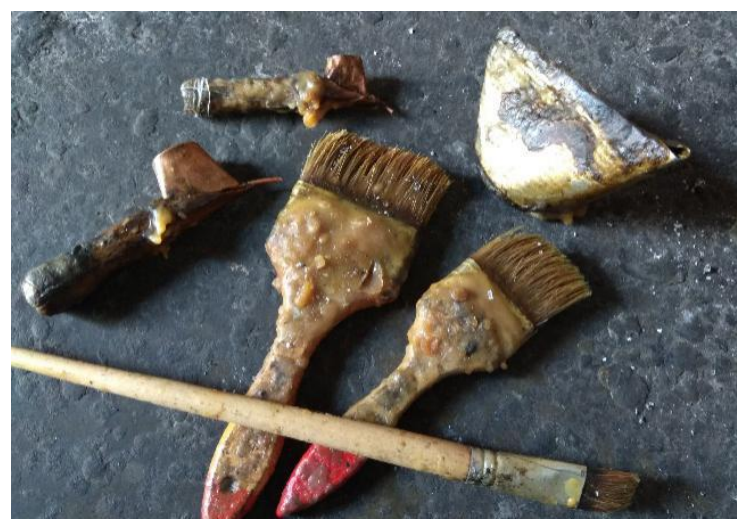

Gambar 8. Alat membuat batik gaya modern yang digunakan Pandono

hati-hati, dan ngrawit. Elemen visual yang tampil dalam karya juga sangat menampilkan karakter laki-laki, yaitu garisgaris yang tebal, spontan, dan tegas.
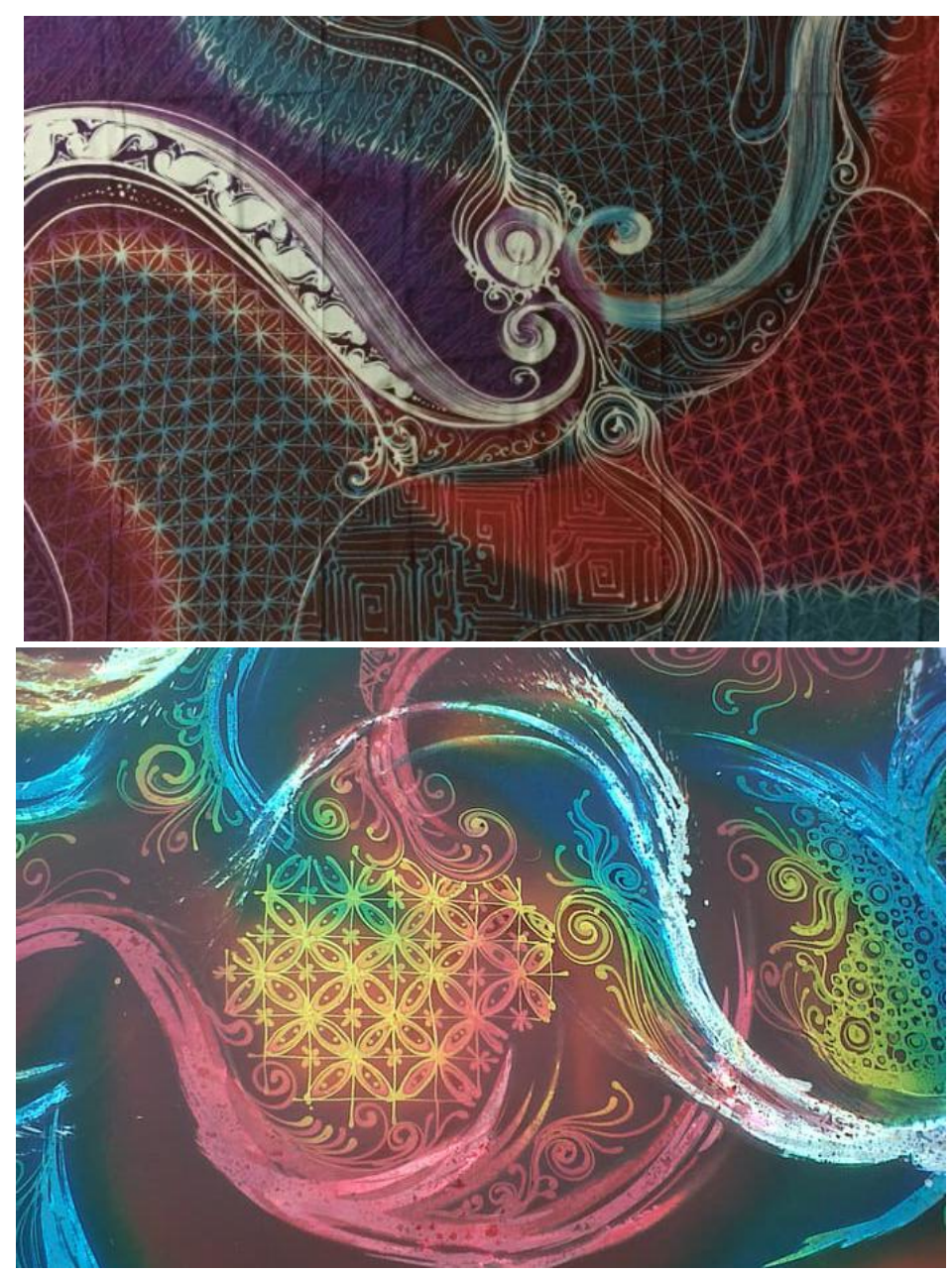

Gambar 9. Karya-karya Pandono yang lain 


\section{KESIMPULAN DAN SARAN}

Wujud batik gaya modern karya Pandono, yang dikembangkan di Surakarta pada awal abad XXI tidak mengacu pada pakem struktur visual batik klasik. Struktur visual batik gaya modern, baik dari aspek elemen visual maupun prinsip desain, relatif berbeda dari batik klasik. Namun demikian, batik gaya modern seringkali masih mengambil bentuk-bentuk khas dari batik klasik untuk diolah dengan prinsip desain yang berbeda sebagi penanda bahwa batik gaya modern tersebut masih terdapat benang merah dengan batik klasik.

Esensi batik gaya modern lebih bersifat profan berbeda dari batik klasik yang bersifat sakral. Batik kontemporer tidak lagi digunakan sebagai media ekspresi doa dan penyampai ajaran seperti halnya pada batik klasik, melainkan sebagai ekspresi keindahan dan sebagai bentuk kecintaannya terhadap tradisi. Kecintaan terhadap tradisi diekspresikan melalui inovasi tradisi bukan pembekuan tradisi, sehingga muncul tradisi yang kekinian, bukan tradisi yang kuno.

\section{KONTRIBUSI PENULIS}

Kontributor utama dalam penulisan artikel ini adalah Sujadi R. Hidayat, dan kontributor anggota adalah Rustopo dan Dharsono. Pengumpulan data dalam pelaksanaan penelitian dilakukan oleh kontributor utama, sedangkan dalam proses analisis dilakukan bersama antara kontributor utama dengan kontributor anggota. Penulisan artikel dilakukan oleh kontributor utama dan editing akhir dilakukan oleh kontributor anggota.

\section{UCAPAN TERIMA KASIH}

Terima kasih kami sampaikan kepada seluruh pihak yang telah mendukung terlaksananya penelitian dan tulisan ini. Kepada Pandono, Saud Effendi, dan Sri Uningsih kami sampaikan terima kasih telah bersedia menjadi sumber data sebagai informan dalam pengumpulan data. Kepada Prof. M. Dwi Marianto, MFA, Ph.D kami sampaikan terima kasih telah memberi penjelasan panjang lebar tentang teori quantum dalam seni. Terima kasih juga kami sampaikan Universitas Sebelas Maret yang telah memberi kesempatan dan biaya untuk studi program doktor, yang mana tulisan ini merupakan bagian dari pelaksanaan program tersebut.

\section{DAFTAR PUSTAKA}

Beardsley, M. C. (1981). Aesthetics, problems in the philosophy of criticism. Hackett Publishing.

Dharsono, S. K. (2007a). Budaya Nusantara, Kajian Konsep Mandala, dan Konsep TriLoka terhadap Pohon Hayat pada Batik Klasik. Bandung: Rekayasa Sains.

Dharsono, S. K. (2007b). Estetika. Rekayasa Sains.

Dharsono, S. K. (2017). Seni Rupa Modern. Bandung: Rekayasa Sains.

Doellah, S. (2002). Batik: Pengaruh Zaman dan Lingkungan. Surakarta: PT. Danarhadi.

Feldman, E. B. (1967). Art, Image and Idea, New Jersey: Prentic-Hall, inc. Englewood Cliffsd, 10.

Fichner-Rathus, L. (2011). Foundations of art and design: An enhanced media edition. Cengage Learning.

Kalinggo Honggodipuro, K. R. T. (2002). Batik Sebagai Busana Dalam Tatanan dan Tuntunan. Surakarta: Yayasan Peduli Karaton Surakarta Hadiningrat.

Marianto, M. D. (2017). Art \& Life Force in a Quantum Perspective. Scritto Books Publisher.

Miles, M. B., \& Huberman, A. M. (1994). Qualitative data analysis: An expanded sourcebook. sage. 
Sanyoto, S. E. (2009). Nirmana Elemen-elemen Seni dan Desain. Yogyakarta: Jalasutra.

Saputro, E. (2009). Batik karya perupa canthing Laweyan antara tahun 2005-2009:: Kajian teknik, bentuk motif, dan gaya seni. Universitas Gadjah Mada.

Soedarso, S. (2006). Trilogi seni: penciptaan, eksistensi, dan kegunaan seni. Badan Penerbit Institut Seni Indonesia Yogyakarta.
Susanto, S. S. K. (1980). Seni Kerajinan Batik Indonesia. Yogyakarta: Balai Penelitian Batik dan Kerajinan.

Sutopo, H. B. (2002). Metodologi penelitian kualitatif. Surakarta: sebelas maret university press.

Suyanto, A. N. (2002). Sejarah Batik Yogyakarta. Rumah Penerbitan Merapi. 